\title{
ДИНАМІЧНЕ 3’СДНАННЯ ФОТОЕЛЕМЕНТІВ В СОНЯЧНИХ ПАНЕЛЯХ
}

Д.В. Бондаренко, канд. техн. наук

Інститут відновлюваної енергетики НАН України, 02094, вул. Гната Хоткевича 20А, м. Київ, Україна.

Метою даної роботи є дослідження принщипів динамічного з'єднання фотоелементів в сонячних панелях. У роботі показано переваги використання таких з'єднань, оскільки розвиток техніки потребує живлення пристроїв з різними напругами та струмами. Відмічено, щуо динамічні з'єднання можуть формувати довільну топологію ланцюгів генерування електричної енергії шляхом зміни з'єднань з послідовних на паралельні і навпаки. Також відмічено, щзо є можливість динамічної зміни параметрів безпосередньо при експлуатації системи. Відзначено, щэо для динамічної коммутації паралельних і послідовних з'єднань потрібно три елементи електричного кола, показно елементарне коло динамічних з'єднань, та коло для динамічної зміни полярності вихідної напруги сонячної панелі. Побудована базова схема динамічної комутації фотоелементів в сонячній панелі з використанням польових транзисторів. Запропоновано шляхи вирішення проблем, які пов 'язані з паралельним з'єднанням та паразитними елементами. Розглянуто використання двох, з 'єднаних на зустріч, МOSFET-транзисторів для динамічної комутації. Відмічено, щзо для керування таким колом доцільно використовувати програмовані логічні контролери, які можуть керувати коммутачією з використанням зазделегідь завантаженої мікропрограми та є гнучкими в оперативному керуванні і мають додаткові функції моніторингу та зв'язку 3 віддаленими пристроями. На прикладі чотирьох фотоелементів показана конструкиія сонячної панелі з динамічними з’єднаннями фотоелементів і використанням SMD-транзисторів та керуванням за допомогою контролера. Відмічено, щзо в такій конструкиї всі елементи можуть бути максимально інтегрованими. Наголомено, щуо застосування динамічної комутації також є кроком до формування змінного струму різної форми. Відмічено певні обмеження запропонованоі системи, зокрема кратність кількості фотоелементів в панелях, та намічено ї̈ подальший розвиток. Бібл. 14, рис. 5 .

Ключові слова: динамічне з'єднання, комутація, сонячна панель, фотоелемент, MOSFET-транзистор, контролер.

\section{DYNAMIC CONNECTION PV-CELLS IN SOLAR PANELS}

D. Bondarenko, candidate of technical science

Institute of Renewable Energy of the National Academy of Sciences of Ukraine, 02094, 20A Hnata Khotkevycha St., Kyiv, Ukraine.

The goal of this work is investigation of principles dynamic connection pv-cells in solar panels. In this paper shown advantages using these connections, that development of technique, require supply devices with different voltages and currents. It is noted that dynamic connections can form any topology of circuits of electricity generation by changing the connections from series to parallel and vice versa. It is also noted that there is a possibility of dynamic change of parameters directly during system operation. Shown that for dynamic commutation parallel and series connections needs three elements of electric circuit. Shown elementary circuit of dynamic connections and circuit for dynamic change of polarity output power of solar panel. Constructed basic circuit of dynamic commutation pv-cells in solar panel with using field transistors. Ways to solve problems related to parallel connection and parasitic elements are suggested. Shown using two, reverse connected, MOSFET-transistors for dynamic commutation. Marked that for control of this circuit advisable using program logic controllers, which can control commutation using early loaded microprogram. and are flexible in operational control and have additional functions of monitoring and communication with remote devices. With example of four pv-cells, shown construction of solar panel with dynamic connection of pv-cells and using SMD-transistors and control of controller. Marked that in this construction all elements could be maximum integrated. It is emphasized that the use of 
dynamic commutation is also a step towards the formation of alternating current of various shapes. Certain limitations of the proposed system are noted, in particular the multiplicity of the number of photocells in the panels, and its further development is planned. Ref.. 14, fig. 5.

Keywords: dynamic connection, commutation, solar panel, pv-element, MOSFET-transistor, controller.

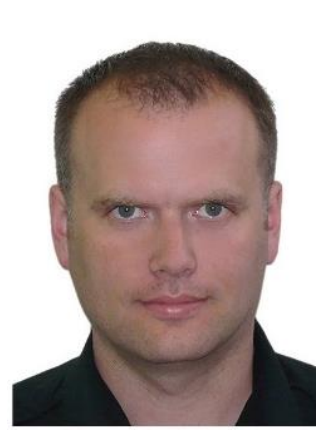

Д.В. Бондаренко

D. Bondarenko
Відомості про автора: Старший науковий співробітник Інституту відновлюваної енергетики НАН України, відділ сонячної енергетики

Освіта: Київський національний університет ім.Т.Шевченка, радіофізичний факультет.

Аспірантура Інституту електродинаміки НАН України

Наукова діяльність: канд. техн. наук (теоретична електротехніка), квантова електроніка, фото- та оптоелектроніка, відновлювана енергетика

Публікації: 46

ORCID: 0000-0002-5629-930X

Контакти: тел: +380509729992

e-mail: dima7007bond@gmail.com
Author information: Senior scientist of Institute of Renewable Energy, National Ukrainian Academy of Science. Solar energy department

Education: Kyiv national university T.Shevchenko, Radiophysics department. Postgraduate school of Institute of electrodynamics of NAS Ukraine Reasearch area: $\mathrm{PhD}$ (theoretical electrotechnic), quantum electronic, photo- and optoelectronic, renewable energy Publications: 46 ORCID: 0000-0002-5629-930X Contacts: tel: +380509729992 , e-mail:dima7007bond@gmail.com
Вступ. Використання фотовольтаїчних генераторів електричної енергії, як для безпосереднього живлення різноманітних споживачів, так і для комплексного застосування, потребує розробки та виробництва таких генераторів 3 великим розмаїттям різних номінальних параметрів. Окрім застосування перетворювальної техніки, яка перетворює сталу напругу i струм в широкий спектр напруг та струмів різної форми, можливе використання послідовно-паралельних з'єднань фотоелементів в ланцюги різної топології для отримання різних номінальних параметрів $[1,2]$. Дійсно, при виробництві сонячних панелей можливе різне розташування та різні з'єднання фотоелементів для отримання необхідних номінальних значень. Недоліком такої конструкції $\epsilon$ статичність, нерегульованість, тобто номінальні параметри не можуть змінюватись динамічно при інсталяції генерувальної системи або навіть при іiі експлуатації.
Постановка завдання. Таким чином, замість використання фіксованих з'єднань в електричних колах фотоелементів пропонується використовувати 3'єднання, які комутуються динамічно. Такі з'єднання можуть формувати довільну або прогнозовано-довільну топологію ланцюгів генерування електричної енергії шляхом зміни з'єднань 3 послідовних на паралельні і навпаки. Тобто номінальні параметри завдяки такій коммутації можуть змінюватись в часі, залежно від потреб споживачів та режимів роботи навантаження.

\section{Елементи динамічних з'єднань.}

Паралельне з'єднання джерел електричної енергії передбачає використання двох з'єднань, які сполучають два одноіменні полюси, а для послідовного з'єднання, використовують одне.

Тобто для реалізації динамічної комутації потрібно використовувати три комутуючих елемента для з'єднання кожних двох генерувальних елементів (рис. 1). Як комутуючі 
елементи можуть виступати, як електромагнітні реле, так i напівпровідникові елементи, наприклад польові транзистори.

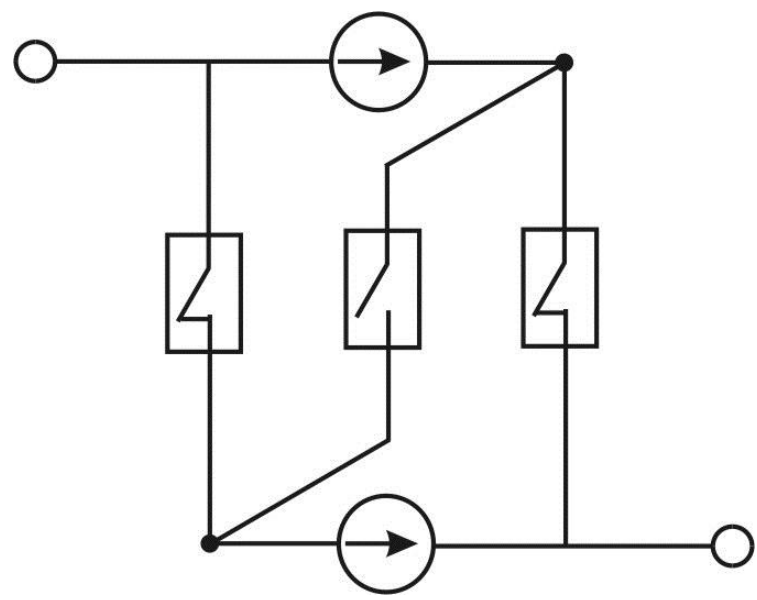

Рис. 1. Динамічна комутація двох джерел живлення

Fig. 1. Dynamic commutation of two sources

Також для коммутації можуть застосовуватись різноманітні збірки ключових елементів у силових мікросхемах, компліментарні збірки, цифрові комутуючі пристрої та драйвери.
Крім того, для зміни полярності вихідної напруги сонячної панелі на вихідних клемах можна використати просту схему зустрічої комутації (рис. 2).

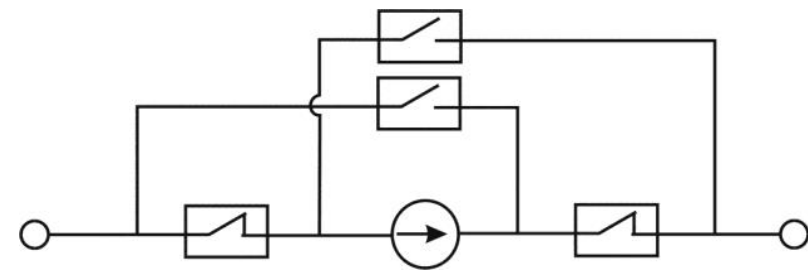

Рис. 2. Схема комутації полярності джерела живлення на вихідних клемах

Fig. 2. Polarity commutation circuit of source on terminals

\section{Базова схема динамічної комутації} фотоелементів. Розглянемо базову схему динамічної комутації чотирьох фотоелементів, які можна з'єднати паралельно, послідовно та паралельно-послідовно (рис. 3). Для комутації використаємо польові МДН-транзистори, які мають низький внутрішній опір. 


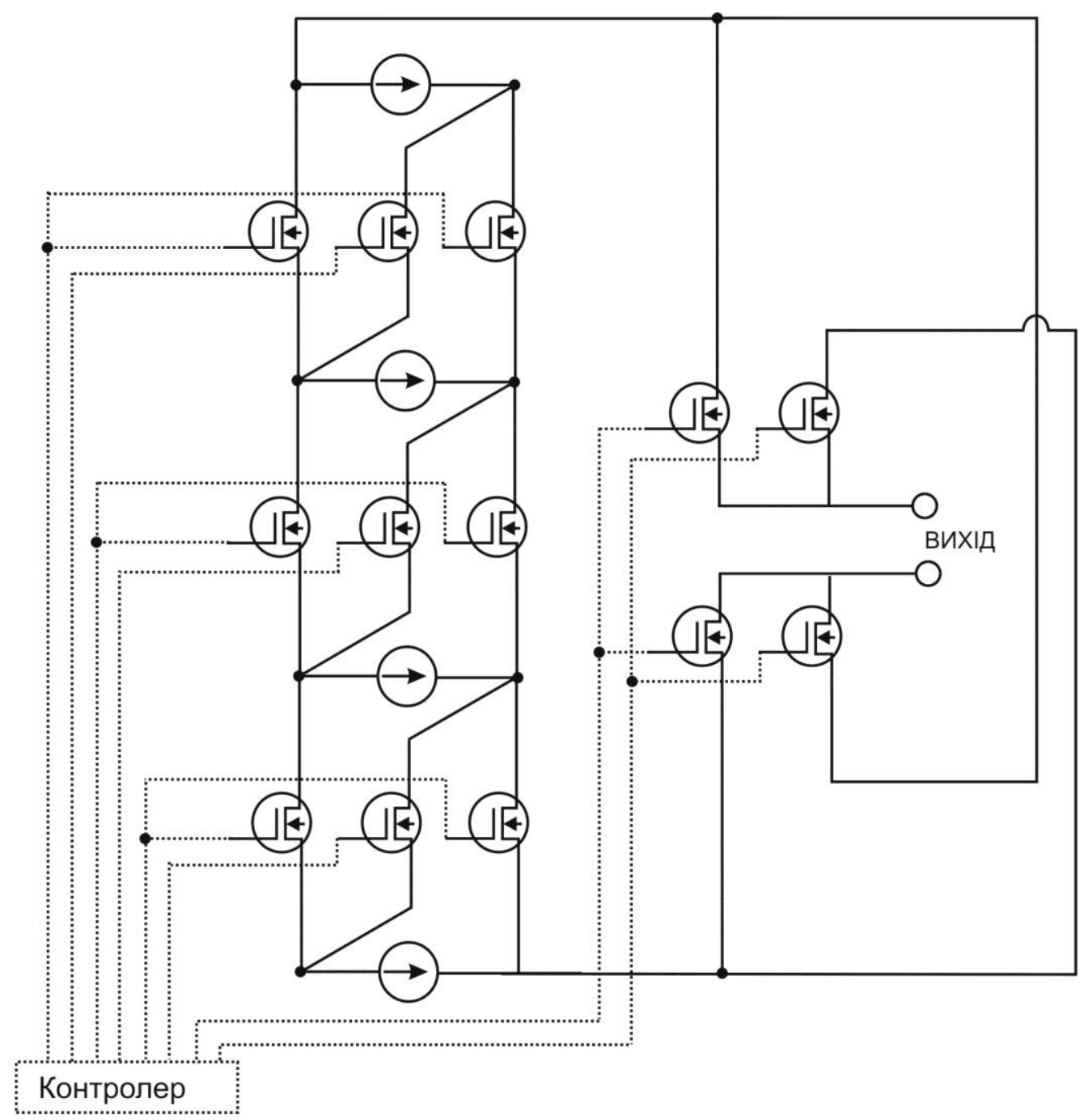

Рис. 3. Приклад динамічної комутації джерел живлення з використанням послідовних та паралельних з'сднань

Fig. 3. Sample of dynamic commutation of sources by using series and parallel connections

Але треба зазначити, що паралельне з'єднання джерел живлення має низку негативних аспектів. Наприклад, в таких колах нерідко виникають вирівнювальні струми [3], які можуть негативно вплинути на джерело живлення 3 меншою напругою генерації та знижувати ефетивність системи в цілому. Здебільшого в цьому разі використовують діоди [4], але звичайні випрямлювальні діоди мають досить велике падіння напруги при прямому включенні, біля 0,6 В. Як альтернативу можливо використовувати діоди Шоткі [5], які при прямому зміщенні мають меньше падіння напруги, але при зворотному зміщенні мають не досить велику напругу пробою, що треба враховувати. Але навіть і в такому разі падіння напруги буде близько 0,3-0,4 B, що для одиночного сонячного елемента також досить суттєво, тому що кремнієвий фотогальванічний елемент генерує 0,5 В напруги [6]. Слід зазначити, що падіння напруги на захисному діоді може нівелюватись при фіксованому з'єднанні декількох фотоелементів послідовно. Більш складним, але сучасним рішенням $\epsilon$ 


\section{використання ORing-діодів [7]. Також як} альтернатива можливе використання самовідновлювальних запобіжників 3 додатним температурним коефіцієнтом разом з діодами або оптореле [8], але це не $є$ універсальними рішеннями.

Крім вищеозначеного, у MOSFETтранзисторів є ще значний недолік - це наявність паразитного діода [9], що унеможливлює нормальну роботу вищеописаної схеми. Для подолання такого недоліку пропонується в кожному плечі паралельного з'єднання джерел живлення замість одного польового транзистора розмістити два, послідовно, 3 зустрічним включенням (рис. 4). Таким чином при подачі на затвор керуючої напруги, відкриються обидва транзистори, а при відсутності напруги вони будуть заперті включеними назустріч паразитними діодами. До речі, якраз на паразитних діодах польових транзисторів 3 ізольованим затвором не виникає падіння напруги, й у деяких джерелах його так i називають - «ідеальний діод» $[10,11]$.

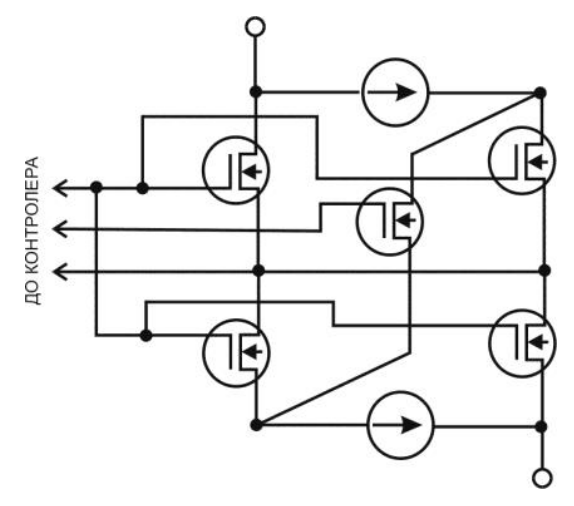

Рис. 4. Динамічна комутація двох джерел живлення за допомогою MOSFET-транзисторів

Fig. 4. Dynamic commutation of two sources by MOSFETtransistors

Також для того щоб в результаті перехідних процессів у комутуючих елементах при перекомутації джерел живлення не виникало вза'ємного короткого замикання між електродами джерел, доцільно використовувати додаткові елементи, які обмежують такі процеси. Крім того, слід здійснювати роздільне керування комутацією з'єднань для паралельного та послідовного включення і при цьому добавляти часовий проміжок між командами закриття та відкриття транзисторів або реле.

Керування комутаційними елементами може здійснюватися за допомогою генераторів стандартних керуючих сигналів або за допомогою програмованих логічних контролерів (ПЛК) [12]. ПЛК містять мікропрограму, яка може динамічно та оперативно здійснювати комутацію з'єднань за встановленим алгоритмом та за командами ззовні. Саме використання програмованих контролерів $€$ доцільним i перспективним в таких системах, оскільки вони окрім широкого спектра керуючих функцій, містять функції з моніторингу та збору даних, такі як напруга і струм на виході, температура панелі тощо [13]. А також ПЛК, завдяки використанню інтегрованих комунікаційних функцій, мають можливість для об'єднання в широкі розгалужені мережі генерації та споживання електроенергії.

\section{Схема динамічної комутації} фотоелементів на сонячній панелі. Отже, виникає можливість реалізувати сонячну панель, яка буде мати цілий спектр номінальних параметрів, крім того ці параметри можуть змінюватись під час генерації елетричної енергії. Для такої реалізації можливо взяти стандартний дизайн сонячної панелі 3 вертикальногоризонтальним розміщенням фотоелементів i внести зміни до з'єднань, включивши до них комутуючі елементи, наприклад транзистори в 
режимі ключа (рис. 5). Комутація елементів може бути реалізована централізовано або розподілено. При розподіленій комутації доцільно використовувати SMD-елементи, які розташовані в сонячній панелі безпосередньо біля кожного 3 фотоелементів або вмонтовані в фотоелементи. Всі елементи в такій конструкції можуть бути максимально інтегрованими. Для керування комутуючих елементів прокладаються додаткові лінії (на рис. 5 позначені пунктиром), які підключаються до пристрою керування контролера.

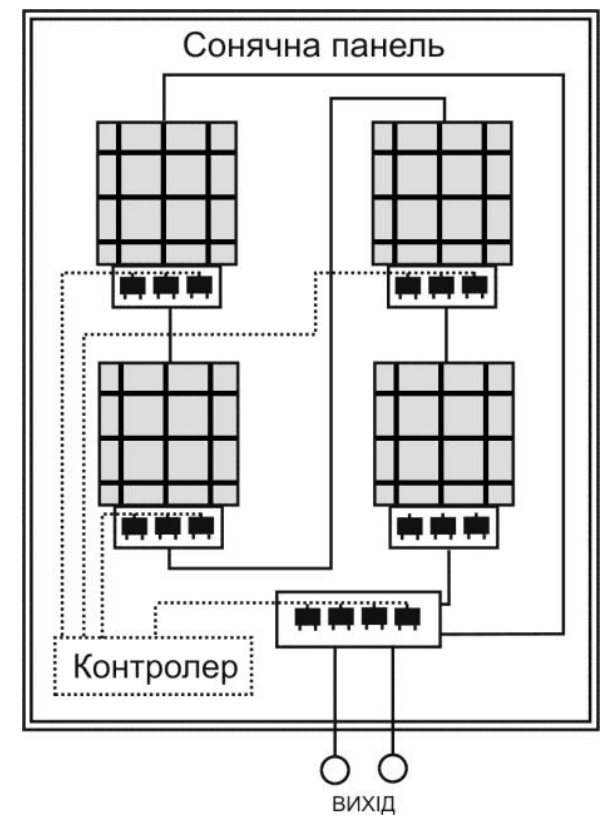

Рис. 5. Конструкція сонячної панелі з розподіленою динамічною комутацісю фотоелементів за допомогою SMD-транзисторів та контролера

Fig. 5. Construction of solar panel with distributed commutation of pv-cells by SMD-transistors and controller

Звісно, для побудови таких електричних систем доцільно виконати моделювання та оптимізаційні розрахунки [14].

Висновок. Таким чином, при застосуванні динамічних з'єднань ми можемо отримти джерело електричної енергії з широким спектром номінальних напруг i струмів. Зазначимо, що використання динамічної комутації дає переваги не тільки при інсталюванні конкретних систем, а й при керуванні пристроями та системами в процесі безпосереднього використання. Наприклад, напруга на навантаженні при споживанні може відрізнятись від напруги заряду акумулятора. Відповідно і з струмом, також $є$ можливість збільшення струму генерації 3 одночасним зниженням напруги. Застосування динамічної комутації також $\epsilon$ кроком до формування змінного струму різної форми.

Обмеженням даної схеми є те, що вихідні напруга i струм будуть кратні $U \cdot 2^{x}$ та $I \cdot 2^{\mathrm{x}}$ відповідно, де $U$ та $I$ - вихідні параметри фотоелемента або вихідні параметри фіксованоз'єднаних декільнох фотоелементів. Подальший розвиток підходу, описаного в роботі, та розвиток таких схем комутації з'єднань полягає в побудові більш універсальних схем взаємного перетворення 3 послідовного в паралельне 3’єднання з можливим використанням множинної комутації.

1. Series and parallel circuits. From Wikipedia. [Електронний ресурс]. URL: https://en.wikipedia.org/wiki/Seri es_and_parallel_circuits (дата звернення: 01.02.2021).

2. Бондаренко Д.В. Моделирование фотоэлементов солнечных батарей с каскадным соединением фотопреобразователей. Відновлювана енергетика. 2007. № 1. C.24-26.

3. Majid Tahmasbi-Fard, Mehrdad Tarafdar-Hagh, Saman Pourpayam, Amir-Aslan Haghrah. A voltage equalized circuit to reduce partial shading effect in photovoltaic string. IEEE Jornal of photovoltaic. 2018. Pp.1-8.

$$
\text { 4. Diode. From Wikipedia. [Електронний ресурс]. }
$$

URL: https://en.wikipedia.org/wiki/Diode (дата звернення: 29.01.2021)

5. Schottky Diode - Working, Characteristics, Applications. From ElectronicsHub. [Електронний pecypc]. URL: https://www.electronicshub.org/schottky-diode-workingcharacteristics-applications/ (дата звернення: 09.11.2018) 
6. Фаренбрух А., Бъюб Р. Солнечные элементы: Теория и эксперимент. Пер. з англ. під ред Колтуна М.M. М. Енергоатоміздат. 1987. 280 с.

7. Patoka M. Fundamentals of power system ORing EDN. [Електронний ресурс].

URL: $\quad$ https://www.edn.com/fundamentals-of-power-systemoring/ (дата звернення: 21.01.2021).

8. LCA717 Single-Pole, Normally Open OptoMOS Relay. IXYS Integrated Circuits. [Електронний pecypc].

URL: https://www.ixysic.com/home/pdfs.nsf/www/LCA717.pdf/ \$file/LCA717.pdf (дата звернення: 26.12.2020).

9. What is the MOSFET body diode? Joshua Israelson. Power electronic tips. [Електронний ресурс].

URL: https://www.powerelectronictips.com/remember-mosfetbody-diode-faq/ (дата звернеяння: 15.12.2020)

10. A simple and inexpensive ideal-diode MOSFET circuit. Aimee Kalnoskas. Power electronic tips. [Електронний pecypc]. URL: https://www.powerelectronictips.com/inexpensiv e-ideal-diode-mosfet-circuit/ (дата звернення: 26.09.2020).

11. Reverse Current/Battery Protection Circuits. Jeff Falin. Application Report SLVA139. [Електронний ресурс]. URL: https://www.ti.com/lit/an/slva139/slva139.pdf (дата звернеяння: 15.12.2020).

12. Microcontroller. From Wikipedia. [Електронний pecypc]. URL: https://en.wikipedia.org/wiki/Microcontroller (дата звернеяння: 15.12.2020)

13. Бондаренко Д.В. Інтелектуальні цифрові фотоелектричні системи. Відновлювана енергетика. 2016. № 1. C. $38-44$.

14. Bondarenko D.V. Use of electrical equivalent circuits at simulation optoelectronic systems. 5th International Workshop on Laser and Fiber-Optical Networks Modeling (Proceedings of LFNM). 2003. Pp. 72-74.

\section{REFERENCES}

1. Series and parallel circuits. From Wikipedia. [Electronic resource]. URL: https://en.wikipedia.org/wiki/Series and parallel circuits (Applying date: 01.02.2021). [in English].

2. Bondarenko D.V. Modelirovanie fotoelementov solnechnyh batarei $\mathrm{s}$ kaskadnym soedineniem fotopreobrazovatelei. [Simulation pv-cells of solar battery with cascade connection pv-elements]. Vidnovluvana energetika. 2007. No. 1. Pp. 24-26. [in Ukrainian].

3. Majid Tahmasbi-Fard, Mehrdad Tarafdar-Hagh, Saman Pourpayam, Amir-Aslan Haghrah. A voltage equalized circuit to reduce partial shading effect in photovoltaic string. IEEE Jornal of photovoltaic. 2018. Pp.1-8. [in English].

4. Diode. From Wikipedia. [Electronic resource]. URL: https://en.wikipedia.org/wiki/Diode (Applying date: 29.01.2021). [in English].

5. Schottky Diode - Working, Characteristics, Applications. From ElectronicsHub. [Electronic resource].

URL: https://www.electronicshub.org/schottky-diode-workingcharacteristics-applications/ (Applying date: 09.11.2018). [in English].

6. Fahrenbruch A., Bube R. Fundamentals of solar cells. Photovolaic solar energy convertion. NY. 1983. 280 p. [in English].

7. Patoka M. Fundamentals of power system ORing. EDN. [Electronic resource]. URL: https://www.edn.com/fundam entals-of-power-system-oring/ (Applying date: 21.01.2021). [in English].

8. LCA717 Single-Pole, Normally Open OptoMOS Relay. IXYS Integrated Circuits. [Electronic resource]. URL: https://www.ixysic.com/home/pdfs.nsf/www/LCA717.pdf/ \$file/LCA717.pdf (Applying date: 26.12.2020). [in English]

9. What is the MOSFET body diode? Joshua Israelson. Power electronic tips. [Electronic resource].

URL: https://www.powerelectronictips.com/remember-mosfetbody-diode-faq/ (Applying date: 15.12.2020). [in English].

10. A simple and inexpensive ideal-diode MOSFET circuit. Aimee Kalnoskas. Power electronic tips. [Electronic resource]. URL: https://www.powerelectronictips.co m/inexpensive-ideal-diode-mosfet-circuit/ (Applying date: 26.09.2020). [in English].

11. Reverse Current/Battery Protection Circuits. Jeff Falin. Application Report SLVA139. [Electronic resource].

URL: https://www.ti.com/lit/an/slva139/slva139.pdf

(Applying date: 15.12.2020). [in English].

12. Microcontroller. From Wikipedia.

[Electronic resource]. URL: https://en.wikipedia.org/wiki/Micro controller (Applying date: 15.12.2020). [in English].

13. Bondarenko D.V. Intelectualni cifrovi fotoelektrychni systemy. [Smart digital photoelectric systems]. Vidnovluvana energetika. 2016. No. 1. Pp. 38-44. [in Ukrainian].

14. Bondarenko D.V. Use of electrical equivalent circuits at simulation optoelectronic systems. 5th International Workshop on Laser and Fiber-Optical Networks Modeling (Proceedings of LFNM). 2003. Pp. 72-74. [in English].

Стаття надійшла до редакції 03.02.21 Остаточна версія 20.09.21 